UDC 543.22+66.011.001.57

\author{
E.B. Khobotova ${ }^{a}$, M.I. Ihnatenko ${ }^{a}$, I.V. Hraivoronska ${ }^{a}$, V.I. Larin ${ }^{b}$
}

\title{
CEMENT DUST FROM BALAKLIIA CEMENT PLANT (UKRAINE): PARTICLE SIZE DISTRIBUTION, CHEMICAL AND RADIONUCLIDE COMPOSITIONS AND POSSIBLE WAYS OF REPROCESSING
}

\author{
a Kharkiv National Automobile and Highway University, Kharkiv, Ukraine \\ ${ }^{b}$ V.N. Karazin Kharkiv National University, Kharkiv, Ukraine
}

\begin{abstract}
Particle size distribution, chemical and radionuclide compositions of cement dust derived from Balakliia Cement Plant (Ukraine) were determined by means of X-ray diffraction analysis, atomic absorption spectrometry, capillary electrophoresis, electron-probe analysis and gamma spectrometry. The changes in the particle size distribution when the cement dust passes through the gas-air duct were determined. In the course of the manufacturing process, the dispersity of the cement dust appreciably increases. It was stated that about $80-86 \%$ of the dust emitted into the atmosphere consists of the particles with the diameter of less than $2.5 \mu \mathrm{m}$. A relatively high content of some metals was revealed in the cement dust. A highly dispersed dust emitted into the atmosphere contained considerable amount of $\mathrm{Cd}, \mathrm{Pb}$ and $\mathrm{Zn}$. The detected natural radionuclides could be dangerous when using the cement dust as a binder or a filler in multicomponent concretes. The cement dust derived from all hoppers is suggested to use without any additional treatment as an additive when grinding the Portland cement clinker and as a raw material component in the production of silica brick and glass. The dust derived from the hopper of a bag filter can be utilized as an indirect fertilizer for acidic soils. The results of the study can be used to model the transfer and precipitation of heavy metal compounds and elaborate nature-conservative measures.
\end{abstract}

Keywords: cement dust, particle size distribution, metals, natural radionuclides, practical guidelines, indirect fertilizer.

DOI: $10.32434 / 0321-4095-2020-132-5-98-103$

\section{Introduction}

Cement production involves many operations that produce cement dust. The main sources of dust are rotary kilns, clinker mills, grinding equipment for raw materials, cement packing and loading processes. About $70-80 \%$ of all cement dust is released by gases leaving the kiln [1]. During the manufacturing process, the concentration of the dust with the particles of less than $10 \mathrm{~mm}$ in diameter increases and reaches $75 \%$ [2]. The burning of raw mix by the dry method yields the most highly dispersed dust $[1,2]$. The efficiency of the used gas cleaning equipment is $95-98 \%$ and $99.9 \%$ for electrostatic filters and bag filters, respectively $[1,2]$.

Cement dust precipitated on the territory around the cement industry enterprises increases the soil $\mathrm{pH}$, deteriorate its structure, and slows down the growth and development of many crops. As a fertilizer, cement dust can be used only for acid soils [3].

Cement production is one of the important sources of atmospheric emissions of toxic dust containing various metals, including heavy metals (HM) [4]. The parameters of airborne transfer of metals are influenced by the chemical composition of emissions and the particle size distribution of metals [1]. The soil contaminated by toxic metals released in the course of cement production is a serious problem in terms of the environmental pollution and people's health, since many metals tend to circulate in the environment for a long time and accumulate in food chains. The study of the spatial distribution of $\mathrm{Cd}$ and $\mathrm{Pb}$ in the upper layers of the soil around cement plants [5] showed that the average concentrations of $\mathrm{Pb}$ and $\mathrm{Cd}$ in the soil were $5.12 \mathrm{mg} / \mathrm{kg}$ and $0.13 \mathrm{mg} / \mathrm{kg}$, respectively. It was stated

(C) E.B. Khobotova, M.I. Ihnatenko, I.V. Hraivoronska, V.I. Larin, 2020 
that the technology-related geochemical anomalies are formed in the soils adjacent to the cement plants, with a significant $\mathrm{Zn}, \mathrm{Cd}, \mathrm{Cu}, \mathrm{Cr}$, and $\mathrm{Pb}$ excess of their respective permissible residual concentrations; in addition, the presence of thallium was detected which is a very dangerous pollutant [6].

The presence of HM in the atmospheric emissions is caused by the use of inorganic additives: pyrite cinder, blast-furnace slag, metallurgical slag, ash and nepheline sludge $[1,2,7]$. The average values of metal concentration in cement clinker emissions decreased in the following sequence: $\mathrm{Zn}>\mathrm{Mn}>\mathrm{Se}>\mathrm{Te}>\mathrm{Sb}>\mathrm{As}>\mathrm{Cr}>\mathrm{Tl}>\mathrm{Pb}>\mathrm{Ni}>\mathrm{Sn}>\mathrm{Cu}>\mathrm{Hg}>\mathrm{Cd}>\mathrm{Co}>\mathrm{V}$ [8]. Refractory metals are usually accumulated in the cement clinker, whereas volatile metals $(\mathrm{Cd}$ and $\mathrm{Hg}$ ) are accumulated in the cement kiln dust [7].

Study [9] reported the content of metals in various samples of cements. It was determined that the concentrations of $\mathrm{Cd}$ is low, the content of $\mathrm{Ca}$, $\mathrm{Ni}$ and $\mathrm{Zn}$ in white structural cement is increased. A high concentrations of $\mathrm{As}, \mathrm{Cu}, \mathrm{Cr}, \mathrm{Mn}, \mathrm{Pb}$ and Fe were detected in the type $\mathrm{V}$ Portland cement. Bismuth was found in all types of cements.

HM ions are fixed in the cement during physical encapsulation, adsorption and isomorphous substitution. With the exception of $\mathrm{Zn}$, the capability of cement materials to adsorb HM increases with increasing $\mathrm{pH}$ and temperature [10]. However, leaching HM from cement [4,11-14] and concrete [4] is possible under certain conditions with their entry into various components of the biosphere. The leaching of metals from cement materials in various environmental conditions determines their environmental safety. The amount of metals leaching from cements in different media decreases in the following order: seawater, groundwater, and acid rain [11]. When exposed to acid rains and groundwater, the amount of leached $\mathrm{Cr}, \mathrm{Ni}, \mathrm{As}$ and $\mathrm{V}$ is inversely proportional to the size of the cement particles. $\mathrm{Cr}$ and $\mathrm{Ba}$ are the most leached metals $[11,12]$. Cements with a high addition of non-clinker components (silica fly ash and granulated blast furnace slag) showed a high degree of immobilization of HM at the level of 99\% [13]. Study of the leaching of certain metals from concrete materials based on waste utilization (fly ash and fly ash from burning solid household waste) showed that the prolonged impact of the cement concrete on the aquatic environment could cause contamination by $\mathrm{Cr}$ and $\mathrm{Cd}$ [14].

The samples of raw materials and products of Balakliia Cement Plant (Balcem), such as various grades of Portland cement and slag Portland cement, were studied in this work. The company uses the
Shebelinske deposit of chalk and clay (Ukraine) as the main source of raw materials. Environmental measures undertaken by Balcem mainly involve emitting reduced volumes of the dust. To this end, cyclones, electric filters for kilns (dry method of cement production) and, bag filters for the clinkergrinding phase were introduced.

The purpose of this study was to determine the particle size distribution, chemical elemental and radionuclide compositions of cement dust and raw materials derived from the Balakliia cement plant to assess the environmental safety of the enterprise. The tasks of the work was to establish the dispersity of cement dust during the technological process, substantiate the correlation between the dispersity of the dust and the content of metals, and suggest practical guidelines on the safe disposal of cement dust fractions.

\section{Experimental}

The particle size distribution of cement dust was determined by scanning electron microscopy using a JSM-6390 LV scanning electron microscope equipped with the INCA micro X-ray analysis system.

The oxide composition of the samples was calculated by the weight content of the mineral phases. X-ray phase analysis, allowing determining the mineral composition of the crystal part of the samples, was performed by means of a Siemens D500 powder diffractometer in copper radiation with a graphite monochromator.

The content of metals was determined by atomic absorption spectrometry using a «Saturn» spectrophotometer. The concentration of metal cations in the aqueous phase was determined by the method of capillary electrophoresis, based on separation of the components of a complex mixture in a quartz capillary under the effect of electric field. The «Capel-104T» apparatus was used to this end.

The specific activity of the natural radionuclides of the samples were determined by the gammaspectrometry method using a SEG-001 «AKP-S» scintillation gamma spectrometer, the range of measured gamma radiation energies being 50$3000 \mathrm{keV}$. The limit of permissible basic error in measuring activity for Marinelli geometry $(\mathrm{P}=0.95)$ is no more than $25 \%$. Akwin software was used to treat the measurement results. Based on the results of a gamma-spectrometric study, the values of specific effective activities of $\mathrm{C}_{\text {ef }}$ samples were calculated according to the following formula:

$$
\mathrm{C}_{\mathrm{ef}}=\mathrm{C}_{\mathrm{Ra}}+1.31 \mathrm{C}_{\mathrm{Th}}+0.085 \mathrm{C}_{\mathrm{K}}, \mathrm{Bq} / \mathrm{kg} \text {. }
$$




\section{Results and discussion}

Particle size distribution of cement dust

Figure 1 shows the experimental results on determining the particle size distribution of cement dust captured at the various sampling points: an electric filter hopper, a gas flue after an electric filter, an exhauster and a cyclone hopper. It is shown that $55 \%$ of the dust at the technological stage of raw mix burning consist of particles with the size of $2.6 \mu \mathrm{m}$ and smaller (Fig. 1,a). At the stage of clinker grinding, the particles with the diameter of more than $3.4 \mu \mathrm{m}$ make up about $50 \%$ (Fig. 1,b). Since the dust samples were taken in the gas duct after the filter, this indicates that the gas cleaning equipment is not efficient enough and needs replacing.

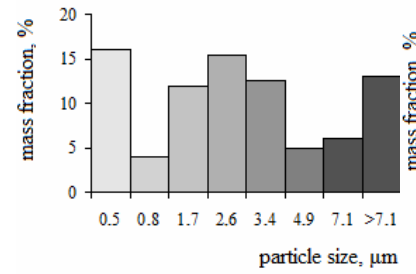

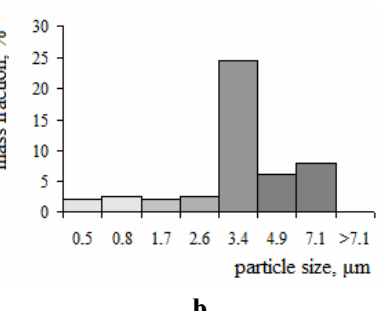

Fig. 1. Particle size distribution in the dust of raw mix burning (a) and in the dust of clinker grinding (b)

The fraction of dust caught by the electric filter is very homogeneous: $90 \%$ of it is represented by particles with the diameter of less than $10 \mathrm{~mm}$ (Fig. 2 , curve 3). After the electric filter, the proportion of smaller particles increases (Fig. 2, curve 4). The dust from the exhauster (Fig. 2, curve 5), which practically can be considered as the dust emitted into the atmosphere, includes $80-86 \%$ of the particles with the size of less than $2.5 \mu \mathrm{m}$. At the grinding stage, polydisperse dust is formed; $50 \%$ of its mass consists of the particles of about $10 \mu \mathrm{m}$. Cement dust is composed of the particles of different shapes with a predominance of elongated ones. In the coarse fractions, there are both individual particles and aggregates of various shapes and densities. The size

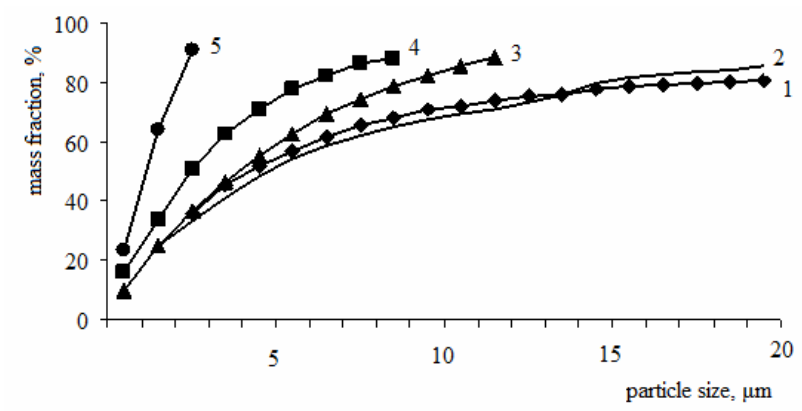

Fig. 2. Particle size distribution at the stage of raw mix burning before the cyclone (1), from the cyclone (2), from electric filter

(3), after electric filter (4) and from the exhauster (5) of large particles can reach 50-100 $\mu \mathrm{m}$ and more.

\section{Chemical composition}

The chemical composition of cement dust was determined at the stage of burning the raw mix (Table 1). Cement dust has a basic character, since the mass fraction of $\mathrm{CaO}$ exceeds the concentration of other oxides. Some other basic oxides are also presented: $\mathrm{MgO}$ (as finely dispersed chimney fraction) and $\mathrm{K}_{2} \mathrm{O}$. In addition, amphoteric oxides $\mathrm{Fe}_{2} \mathrm{O}_{3}$ and $\mathrm{Al}_{2} \mathrm{O}_{3}$ as well as acid oxide $\mathrm{SiO}_{2}$ were detected. The concentrations of $\mathrm{SiO}_{2}$ and $\mathrm{Al}_{2} \mathrm{O}_{3}$ are considerably reduced in highly dispersed dust fractions, suggesting that the content of calcium silicates and aluminates in them is decreased as compared with calcium ferrites.

Table 1

Composition of the dust at the stage of burning of raw mix for cement production

\begin{tabular}{l|c|c|c|c|c|c}
\hline \multirow{2}{*}{ Place of extraction } & \multicolumn{6}{|c}{ Mass fraction of oxide, \% } \\
\cline { 2 - 7 } & $\mathrm{Fe}_{2} \mathrm{O}_{3}$ & $\mathrm{CaO}$ & $\mathrm{SiO}_{2}$ & $\mathrm{Al}_{2} \mathrm{O}_{3}$ & $\mathrm{MgO}$ & $\mathrm{K}_{2} \mathrm{O}$ \\
\hline Before refining & - & 48.1 & 28.0 & 6.4 & - & 4.1 \\
\hline $\begin{array}{l}\text { Electrostatic } \\
\text { precipitator hopper }\end{array}$ & 2.0 & 46.2 & 16.2 & 2.5 & - & 5.8 \\
\hline $\begin{array}{l}\text { Gas flue after } \\
\text { electrostatic } \\
\text { precipitator }\end{array}$ & 1.1 & 49.3 & 8.2 & 2.5 & - & - \\
\hline Exhauster & $<1$ & 49.7 & 8.6 & 2.2 & 4.5 & $<1$ \\
\hline
\end{tabular}

The content of metals in the raw material and in fractions of cement dust of various degrees of dispersion

The content of metals in raw materials is shown in Table 2. All raw materials are characterized by the presence of metals, but their concentration can vary widely. Low metals concentrations are characteristic of chalk, gypsum and blast furnace slag. The highest content of all detected metals (with the exception of $\mathrm{Ni}$ ) is typical of pyrite cinders; the ash form the thermal power plant comes next. These raw materials are the concentrators of metal ions as they were exposed to preliminary high-temperature processing with burning organic components. Pyrite cinders contain the highest amount of metals, so either they must be replaced with pyrite cinders from another source, or replaced with an alternative material of similar chemical composition. In any case, the use of pyrite cinders must be preceded by a chemical analysis of the content of metals.

A sufficiently high content of metals observed in cement dust formed at various stages of the technological process, with a significant variation in their concentrations $(\mathrm{mg} / \mathrm{kg}): 0.75-420,20-4280$, $180-2460$ and $10-190$ for $\mathrm{Cd}, \mathrm{Pb}, \mathrm{Zn}$ and $\mathrm{Cr}$, respectively. The content of $\mathrm{Hg}$ is low. It can be 
assumed that the fluctuations in metal concentrations are associated either with the changes in the composition of slag additives or pyritic cinders or with the change in the operating mode of kilns, deposition conditions in the cleaning system and some other factors. The data given in Table 3 characterize the content of metals in the cement dust at different process stages. The dust samples after the electrostatic precipitator are primarily enriched with $\mathrm{Zn}, \mathrm{Pb}$ and $\mathrm{Cd}$. The dust of the electric filter additionally contains $(\mathrm{mg} / \mathrm{kg}): 96$ and 13,800 of $\mathrm{Mn}$ and $\mathrm{Sr}$, respectively.

Table 2

Content of metals in feed raw material of cement production

\begin{tabular}{l|c|c|c|c|c|c}
\hline \multirow{2}{*}{ Component } & \multicolumn{6}{|c}{ Content of metal, $\mathrm{mg} / \mathrm{kg}$} \\
\cline { 2 - 8 } & $\mathrm{Hg}$ & $\mathrm{Cu}$ & $\mathrm{Ni}$ & $\mathrm{Zn}$ & $\mathrm{Pb}$ & $\mathrm{Cd}$ \\
\hline Chalk & 0.04 & 2.7 & 4.2 & 20.9 & 2.5 & 0.2 \\
\hline Clay & 0.07 & 23.1 & 31.2 & 62.8 & 11.8 & 0.25 \\
\hline Blast-furnace slag & 0.01 & 1.7 & 2.6 & 4.3 & 0.4 & 0.13 \\
\hline Gypsum stone & 0.01 & 2.1 & 4.6 & 5.1 & 0.35 & 0.18 \\
\hline Pyritic cinders & 2.2 & 2680 & 15.8 & 7380 & 1208 & 15.1 \\
\hline Phosphogypsum & - & 6.0 & 4.9 & 25.6 & 0.75 & 0.07 \\
\hline $\begin{array}{l}\text { Ash from thermal } \\
\text { power plant }\end{array}$ & 0.12 & 32.8 & 21.2 & 175.7 & 11.7 & 0.4 \\
\hline
\end{tabular}

Content of metals in cement dust

\begin{tabular}{l|c|c|c|c|c|c|c|c}
\hline \multirow{2}{*}{ Cleaning stage } & \multicolumn{7}{|c}{ Mass fraction of the element, mg/g } \\
\cline { 2 - 8 } & $\mathrm{As}$ & $\mathrm{Cd}$ & $\mathrm{Cr}$ & $\mathrm{Cu}$ & $\mathrm{Ni}$ & $\mathrm{Pb}$ & $\mathrm{Zn}$ \\
\hline & \multicolumn{7}{|c}{ Raw mix burning } \\
\hline Before refining & 29 & 51 & 10 & 58 & 4.5 & 500 & 209 \\
\hline $\begin{array}{l}\text { Electrostatic } \\
\text { precipitator }\end{array}$ & 20 & 94 & 34 & 62 & 5.9 & 1690 & $190-390$ \\
\hline
\end{tabular}

\begin{tabular}{l|l|l|l|l|l|l|l}
\hline Bag dust filter & - & 0.72 & - & 70 & 15 & 7.8 & 254 \\
\hline
\end{tabular}

Table 4

Size distribution of metals dust particles

\begin{tabular}{c|c|c|c}
\hline \multirow{2}{*}{$\begin{array}{c}\text { Particle size, } \\
\mu \mathrm{m}\end{array}$} & \multicolumn{3}{|c}{ Mass fraction of the element, $\mathrm{mg} / \mathrm{g}$} \\
\cline { 2 - 4 } & $\mathrm{Cd}$ & $\mathrm{Pb}$ & $\mathrm{Cu}$ \\
\hline$<2.5$ & 290 & 8700 & 540 \\
\hline $2.5-5.0$ & 62 & 870 & 180 \\
\hline$>5.0$ & 53 & 760 & 110 \\
\hline
\end{tabular}

The distribution of metals was studied depending on the dispersion of dust particles. Experimental data are summarized in Table 4. The enrichment factor of high-dispersion fraction in relation to low dispersion fraction is equal to 6.2 , 10.6 and 3.8 for $\mathrm{Cd}, \mathrm{Pb}$ and $\mathrm{Cu}$, respectively. Thus, the highest enrichment of dust dispersion particles by lead and cadmium has been discovered.

Radionuclide composition of cement dust

Gamma-spectrometry method detected the presence of radionuclides of uranium and thorium radioactive families as well as ${ }^{40} \mathrm{~K}$ in the cement dust. Experimental and calculated data are given in Table 5. The presence of ${ }^{214} \mathrm{~Pb}$ and ${ }^{214} \mathrm{Bi}$ nuclides in the dust is the evidence of the decay of the parent radionuclide ${ }^{226} \mathrm{Ra} .{ }^{40} \mathrm{~K}$ isotope makes the main contribution to the total cement activity (92.8\%). Based on the values of specific radioactivity, the effective specific activity $\mathrm{C}_{\mathrm{ef}}=313 \mathrm{~Bq} / \mathrm{kg}$ was calculated, this value can be used for comparative assessments of the radioactivity of raw materials and materials. According to calculated $\mathrm{C}_{\mathrm{ef}}$, the materials under study belong to the class I of radiation hazard and it can be used in construction without any restrictions, since the condition $\mathrm{C}_{\mathrm{ef}} \leq 370 \mathrm{~Bq} / \mathrm{kg}$ is satisfied. However, the obtained value of $\mathrm{C}_{\text {ef }}$ is still significantly higher than the maximum allowed average $\mathrm{C}_{\mathrm{ef}}$ in the CIS $(93 \mathrm{~Bq} / \mathrm{kg})$ and in Ukraine $(106 \mathrm{~Bq} / \mathrm{kg})$ [15]. The use of this cement dust as a binder and a filler can cause an increase in the effective specific activity of concrete as a multicomponent material and an increase in the absorbed gamma radiation dose for people.

Table 5

Results of gamma spectrometry analysis of cement dust derived from electrostatic precipitator

\begin{tabular}{c|c}
\hline Isotopes & Specific activities of radionuclides, Bq/kg \\
\hline${ }^{214} \mathrm{~Pb}$ & 8.86 \\
\hline${ }^{214} \mathrm{Bi}$ & 60 \\
\hline${ }^{228} \mathrm{Ac}$ & 24 \\
\hline${ }^{232} \mathrm{Th}$ & 24 \\
\hline${ }^{212} \mathrm{Bi}$ & 142 \\
\hline${ }^{40} \mathrm{~K}$ & 3310 \\
\hline
\end{tabular}

Guidelines on the usage of cement dust

A low-waste production implies the use of the collected dust. Depending on the composition, cement dust can be utilized in various ways. Most often, dust is returned to the kiln using a pneumatic screw pump. The main condition here is to provide a low content of alkali metal oxides $\mathrm{K}_{2} \mathrm{O}$ and $\mathrm{Na}_{2} \mathrm{O}$, not more than $0.7-0.8 \%$ [1]. In this case, only cement dust from the exhauster meets this requirement (Table 1). The dust from the electric filter hopper contains $5.8 \% \quad \mathrm{~K}_{2} \mathrm{O}$; therefore, a preliminary leaching stage is necessary before feeding it into the kiln.

All types of cement dust, including those containing metals (dust from the electric filter hopper), can be used in the following ways: as additive 
when grinding Portland cement clinker; as raw material component when manufacturing silicate bricks; and as raw alkaline component in glass production $[1,2]$.

Low-dispersed dust fractions (dust from a bag filter), which have lower metals content, can be used as a fertilizer to improve the soil structure and increase the $\mathrm{pH}$ of acidic soils $[2,3]$.

\section{Conclusions}

The changes in the particle size distribution were investigated for the cement dust of the Balakliia cement plant, when the dust passes through the gasair duct. During the process, the dispersity of the cement dust considerably increases. About $80-86 \%$ of the dust emitted into the atmosphere consists of the particles with the diameter of less than $2.5 \mu \mathrm{m}$. It was stated that the gas cleaning equipment is not efficient enough at the stage of grinding.

It was revealed that the dust of cement production has a high content of several metals. Highly dispersed dust emitted into the atmosphere contains $\mathrm{Cd}, \mathrm{Pb}$ and $\mathrm{Zn}$. Natural radionuclides were identified in the cement dust, they may be dangerous when using cement dust as a binder and a filler in multicomponent concretes.

Cement dust from all hoppers without additional processing can be suggested to use as an additive when grinding Portland cement clinker and as a raw material component in silicate bricks and glass productions. Dust from the hopper of a bag filter can be used as an indirect fertilizer for acidic soils.

The results of this work should be used when choosing the raw materials with the lowest metal content, evaluating the efficiency of gas cleaning equipment, environmental modeling of the transfer and sedimentation of metal compounds and elaborating environmental measures.

\section{REFERENCES}

1. To determine the actual particle size of dust emissions from the construction industry and construction / Azarov V.N., Koshkarev S.A., Nikolenko M.A. // Inzhenernyi Vestnik Dona. - 2015. - No. 1. - Part 2. - 13 p.

2. Chomayeva M.N. Ecology of cement production // Int. J. Hum. Nat. Sci. - 2019. - Vol.2-1. - P.8-10.

3. Pasika K.A. Research of effect of cement dust emissions on growth and development of plants // Uspekhi Sovremennogo Estestvoznaniya. - 2004. - No. 11. - P.45-45.

4. Krol A. Problems of assessment of heavy metals leaching from construction materials to the environment // Archit. Civ. Eng. Environ. - 2011. - No. 3. - P.71-76.
5. Solgi E., Khodabandelo H. Cadmium and lead disruption in soils around the Hegmatan cement factory, Iran // Health Scope. - 2016. - Vol.5. - Article No. e34184.

6. Korolev A.N., Boev V.A. Heavy metals in soils and vegetable cultures in the zone of influence of cement factory of city of Semey (Republic of Kazakhstan) // Vestnik Omskogo GAU. - 2017. - Vol.3. - No. 27. - P.74-79.

7. Distribution of heavy metals in Portland cement production process / Cipurkovic A., Trumic I., Hodzic Z., Selimbasic V., Djozic A. // Adv. Appl. Sci. Res. - 2014. - Vol.5. - No. 6. - P.252-259.

8. Assessment of heavy metals released into the air from the cement kilns co-burning waste: case of Oujda cement manufacturing (Northeast Morocco) / Arfala Y., Douch J., Assabbane A., Kaaouachi K., Tian H., Hamdani M. // Sustainable Environ. Res. - 2018. - Vol.28. - No. 6. - P.363-373.

9. Analysis of metal contents in Portland type V and MTAbased cements / Dorileo M.C., Bandeca M.C., Pedro F.L., Volpato L.E., Guedes O., Dalla Villa R., Tonetto M., Borges A. // Sci. World J. - 2014. - Vol.2014. - Article No. 983728.

10. Impact of $\mathrm{pH}$ value and temperature on cement-based materials adsorbing heavy metal ions / Wang Y., Cui S., Xu X., Lan M. // Mater. Sci. Forum. - 2016. - Vol.847. - P.265-271.

11. Leaching of metals from cement under simulated environmental conditions / Lu H., Wei F., Tang J., Giesy J.P. // J. Environ. Manage. - 2016. - Vol.169. - P.319-327.

12. $O$ Eckert J., Guo $Q$. Heavy metals in cement and cement kiln dust from kilns co-fired with hazardous waste-derived fuel: application of EPA leaching and acid-digestion procedures // J. Hazard. Mater. - 1998. - Vol.59. - P.55-93.

13. Kuterasinska-Warwas Yu., Krol A. Leaching of heavy metals from cementitious composites made of new ternary cements // E3S Web Conf.- 2017. - Vol.19. - No. 02019.

14. Yuan X. Leaching behavior of heavy metals from cement pastes containing solid wastes // IOP Conf. Ser. Earth Environ. Sci. - 2018. - Vol.186. - Article No. 012043.

15. Kovalenko G.D., Rudia K.G. Radioekologiya Ukrainy. - Kyiv: Publishing and Printing Center «Kyiv University», 2001. $-167 \mathrm{p}$.

Received 25.06.2019

\section{ЦЕМЕНТНИЙ ПИЛ БАЛАКЛІЙСЬКОГО ЦЕМЕНТНОГО ЗАВОДУ (УКРАЇНА): ДИСПЕРСНИЙ, ХІМІЧНИЙ І РАДІОНУКЛІДНИЙ СКЛАЛИ ТА ПОТЕНЦЙНІ ШЛЯХИ ПОВТОРНОГО ПЕРЕРОБЛЕННЯ \\ Е.Б. Хоботова, М.І. Іенатенко, І.В. Грайворонська, B.I. Ларін}

За допомогою рентгенофазового аналізу, атомно-абсорбційної спектроскопії, капілярного електрофорезу, електронної мікроскопії і гамма-спектрометричного методу визначено дисперсний, хімічний і радіонуклідний склади цементного пилу Балаклійського цементного заводу (Україна). Встановлено зміни дисперсного складу пилу при про- 
ходженні газоповітряного тракту. Показано, що при протіканні технологічного процесу дисперсність цементного пилу значно зростає. Пил, що викидається в атмосферу, на $80-86 \%$ складається з частинок 3 діаметром $<2,5$ мкм. Вставлено високий вміст низки металів в пилу цементного виробництва та концентрування $\mathrm{Cd}, \mathrm{Pb}$ i $\mathrm{Zn}$ високодисперсним пилом, що викидається в атмосферу. Виявлені природні радіонукліди можуть становити небезпеку при використанні цементного пилу як в'яжучого і наповнювача в багатокомпонентних бетонах. Рекомендовано використовувати цементний пил з усіх бункерів без додаткового оброблення як добавку при помелі портландцементного клінкера та як сировинний компонент при виготовленні силікатної цегли і скла. Пил з бункера рукавного фільтра можна використовувати як непряме добриво для кислих грунтів. Результати роботи можуть бути використані при моделюванні перенесення і висаджування сполук важких металів і при розробці природоохоронних заходів.

Ключові слова: цементний пил, дисперсний склад, метали, природні радіонукліди, практичні рекомендації, непряме добриво.

\section{CEMENT DUST FROM BALAKLIIA CEMENT PLANT (UKRAINE): PARTICLE SIZE DISTRIBUTION, CHEMICAL AND RADIONUCLIDE COMPOSITIONS AND POSSIBLE WAYS OF REPROCESSING}

\author{
E.B. Khobotova ${ }^{a,}{ }^{*}$, M.I. Ihnatenko ${ }^{a}$, I.V. Hraivoronska ${ }^{a}$, \\ V.I. Larin $^{b}$
}

a Kharkiv National Automobile and Highway University, Kharkiv, Ukraine

b V.N. Karazin Kharkiv National University, Kharkiv, Ukraine

* e-mail: elinahobotova@gmail.com

Particle size distribution, chemical and radionuclide compositions of cement dust derived from Balakliia Cement Plant (Ukraine) were determined by means of X-ray diffraction analysis, atomic absorption spectrometry, capillary electrophoresis, electron-probe analysis and gamma spectrometry. The changes in the particle size distribution when the cement dust passes through the gas-air duct were determined. In the course of the manufacturing process, the dispersity of the cement dust appreciably increases. It was stated that about $80-86 \%$ of the dust emitted into the atmosphere consists of the particles with the diameter of less than $2.5 \mu \mathrm{m}$. A relatively high content of some metals was revealed in the cement dust. A highly dispersed dust emitted into the atmosphere contained considerable amount of $\mathrm{Cd}, \mathrm{Pb}$ and $\mathrm{Zn}$. The detected natural radionuclides could be dangerous when using the cement dust as a binder or a filler in multicomponent concretes. The cement dust derived from all hoppers is suggested to use without any additional treatment as an additive when grinding the Portland cement clinker and as a raw material component in the production of silica brick and glass. The dust derived from the hopper of a bag filter can be utilized as an indirect fertilizer for acidic soils. The results of the study can be used to model the transfer and precipitation of heavy metal compounds and elaborate nature-conservative measures.

Keywords: cement dust; particle size distribution; metals; natural radionuclides; practical guidelines; indirect fertilizer.

\section{REFERENCES}

1. Azarov V.N., Koshkarev S.A., Nikolenko M.A. K opredeleniyu fakticheskikh razmerov chastits pyli vybrosov stroiindustrii i stroitel'stva [To determine the actual particle size of dust emissions from the construction industry and construction]. Inzhenernyi Vestnik Dona, 2015, no. 1, part 2, pp. 13. (in Russian).

2. Chomayeva M.N. Ekologiya proizvodstva tsementa [Ecology of cement production]. International Journal of Humanities and Natural Sciences, 2019, vol. 2-1, pp. 8-10. (in Russian)

3. Pasika K.A. Issledovaniye vliyaniya vybrosov tsementnoy pyli na rost i razvitiye rastenii [Research of the effect of cement dust emissions on the growth and development of plants]. Uspekhi Sovremennogo Estestvoznaniya, 2004, no. 11, pp. 45-45. (in Russian).

4. Krol A. Problems of assessment of heavy metals leaching from construction materials to the environment. Architecture. Civil Engineering. Environment, 2011, no. 3, pp. 71-76.

5. Solgi E., Khodabandelo H. Cadmium and lead disruption in soils around the Hegmatan cement factory, Iran. Health Scope, 2016, vol. 5, article no. e34184.

6. Korolev A.N., Boev V.A. Tyazhelye metally v pochvakh i ovoshchnykh kul'turakh $\mathrm{v}$ zone vliyaniya tsementnogo zavoda goroda Semey (Respublika Kazakhstan) [Heavy metals in soils and vegetable cultures in the zone of influence of cement factory of city of Semey (Republic of Kazakhstan)]. Vestnik Omskogo GAU, 2017, vol. 3, no. 27, pp. 74-79. (in Russian).

7. Cipurkovic A., Trumic I., Hodzic Z., Selimbasic V., Djozic A. Distribution of heavy metals in Portland cement production process. Advances in Applied Science Research, 2014, vol. 5, no. 6, pp. 252-259.

8. Arfala Y., Douch J., Assabbane A., Kaaouachi K., Tian H., Hamdani M. Assessment of heavy metals released into the air from the cement kilns co-burning waste: case of Oujda cement manufacturing (Northeast Morocco). Sustainable Environment Research, 2018, vol. 28, pp. 363-373.

9. Dorileo M.C., Bandeca M.C., Pedro F.L., Volpato L.E., Guedes O.A., Dalla Villa R., Tonetto M.R., Borges A.H. Analysis of metal contents in Portland type V and MTA-based cements. Scientific World Journal, 2014, vol. 2014, article no. 983728.

10. Wang Y.L., Cui S.P., Xu X.K., Lan M.Z. Impact of $\mathrm{pH}$ value and temperature on cement-based materials adsorbing heavy metal ions. Materials Science Forum, 2016, vol. 847, pp. 265-271.11. Lu H., Wei F., Tang J., Giesy J.P. Leaching of metals from cement under simulated environmental conditions. Journal of Environmental Management, 2016, vol. 169, pp. 319-327. 12. O Eckert J., Guo Q. Heavy metals in cement and cement kiln dust from kilns co-fired with hazardous waste-derived fuel: application of EPA leaching and acid-digestion procedures. Journal of Hazardous Materials, 1998, vol. 59, pp. 55-93.

13. Kuterasinska-Warwas Yu., Krol A. Leaching of heavy metals from cementitious composites made of new ternary cements. E3S Web of Conferences, 2017, vol. 19, no. 02019.

14. Yuan X. Leaching behavior of heavy metals from cement pastes containing solid wastes. IOP Conference. Series: Earth and Environmental Science, 2018, vol. 186, no. 012043.

15. Kovalenko G.D., Rudia K.G., Radioekologiya Ukrainy [Radioecology of Ukraine]. Kyiv University Publishers, Kyiv, 2001. 167 p. (in Russian). 